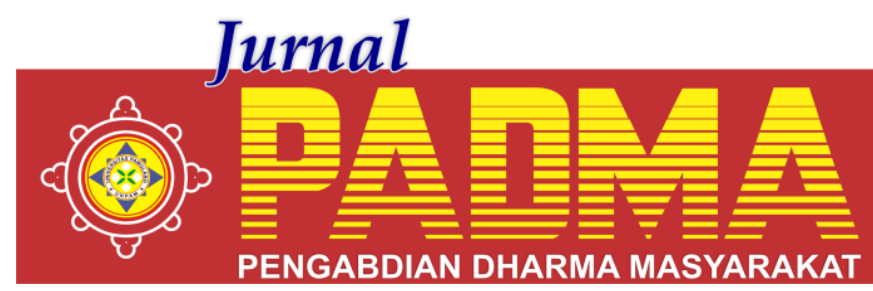

VOLUME 1, NOMOR 2, APRIL 2021

\title{
PELATIHAN PEMBUATAN FACEBOOK AD DI UMKM DI SENTRA KAMPOENG RAJOET BINONG JATI
}

\author{
${ }^{1 *}$ Agatha Rinta Suhardi, ${ }^{2}$ Vina Silviani Marinda, ${ }^{3}$ Arus Reka Prasetia, ${ }^{4}$ Titto Rohendra, \\ ${ }^{5}$ Andi Budiawan \\ Universitas Widyatama, Bandung, Jawa Barat, Indonesia \\ *agatha.rinta@widyatama.ac.id
}

\begin{abstract}
Abstrak
Di Indonesia, industri rajut mulai berkembang dan menjadi salah satu faktor pendukung industri fashion yang semakin bervariasi. Penggunaan teknologi internet menjadi target penting dari pemerintah Indonesia untuk meningkatkan promosi penjualan dari industry rajut itu sendiri. Tujuan kegiatan ini adalah untuk memberikan penyelenggaraan pelatihan pembuatan facebook ad guna membantu para pengrajin rajut dalam memasarkan dan memperkenalkan produknya melalui internet sehingga penjualan industri rajut semakin meningkat, inovatif, kreatif, mandiri serta berdaya saing. Metode pelaksanaan adalah dengan memberikan pelatihan, memberikan implementasi dan contoh facebook ad untuk peningkatan penjualan melalui informasi yang diberikan dalam facebook ad. Materi yang disampaikan pada kegiatan PKM mencapai target cukup baik sebab materi pelatihan dan implementasi facebook ad serta beberapa peserta sudah ada yang memiliki facebook ad dalam memperkenalkan produk-produknya sehingga dapat mengembangkan peluang usaha yang dapat menghasilkan profit secara maksimal.
\end{abstract}

Kata Kunci : Pelatihan, Facebook ad, Sentra Rajut

\section{Abstract}

In Indonesia, the knitting industry began to develop and became one of the factors supporting the increasingly varied fashion industry. The use of internet technology is an important target of the Indonesian government to increase sales promotion of the knitting industry itself. The purpose of this activity is to provide training on making Facebook ad to help knitting craftsmen in marketing and introducing their products via the internet so that sales of the knitting industry are increasing, innovative, creative, independent and competitive. The method of implementation is to provide training, provide implementation and examples of facebook ad to increase sales through the information provided in facebook ad. The material presented at the PKM activity reached the target quite well because the training material and the implementation of Facebook ad and some of the participants already had Facebook ad in introducing their products so that they could develop business opportunities that could generate maximum profit.

Keywords: Training, Facebook ad, Knitting Center

\section{PENDAHULUAN}

Kampoeng Rajoet Binong jati terletak di sebelah timur Bandung Raya. Industri ini dimulai dengan 5 pengrajin yang memulai usaha ini dengan sistem maklun dari pabrik besar. Di tahun 70-an industri rajut ini mulai menggunakan mesin flat knitting yang dikembangkan oleh sekitar 10 pengrajin. Pada saat krisis moneter terjadi lonjakan besar pertumbuhan pengrajin yang mencapai 250 pengrajin. Saat ini sudah ada 400 pengrajin yang berprofesi di bidang rajut. Sampai saat ini Kampoeng Rajoet Binong Jati yang menghasilkan tiap bulan kurang lebih 4500 lusin pakaian rajut aneka jenis dan mempekerjakan lebih dari 9000 orang.

Kampoeng Rajoet Binong Jati memiliki rencana pengembangan usaha meliputi strategi pemasaran, strategi produksi, strategi organisasi dan tenaga kerja. Strategi pemasaran antara lain membuat sampel desain produk untuk dipresentasikan ke distributor/retailer, pengembangan wilayah distribusi pemasaran, pengembangan saungsaung penjualan di kampoeng rajoet dengan memanfaatkan tanah kosong milik Pemkot, pengembangan show windows untuk produk-produk pilihan di sekitas Jalan Gatot Subroto/Kiaracondong yang letaknya dalam area kelurahan Binong, 500 meter dari Trans 
Studio Mall (TSM). Strategi produksi meliputi perbaikan desain sesuai dengan mode yang terbaru dan peningkatan produkstivitas tenaga kerja. Strategi organisasi dan tenaga kerja antara lain perubahan struktur manajemen dan organisasi dan penarikan tenaga kerja yang terampil. Tahapan pengembangan usaha dilakukan melalui kegiatan restrukturisasi manajemen dan organisasi, peningkatan produktivitas tenaga kerja, promosi penjualan melalui pameran, penjajakan perluasan wilayah pemasaran.

Kampoeng Rajoet Binong Jati terletak di Kelurahan Binong Kecamatan Batununggal. Fokus dari industri ini adalah memproduksi berbagai jenis pakaian berbahan benang yang dilakukan dengan menggunakan mesin flat knitting. Kampoeng Rajoet Binong Jati memiliki rencana inovasi dengan pemanfaatan e-commerce di bidang pemasaran antara lain mencari peluang pasar pada situs-situs online, mencakup pasar yang lebih luas baik domestik maupun luar negeri, membuat konten yang menarik melalui foto produk yang professional. Rencana inovasi di bidang produksi melalui pembuatan sistem manajemen produksi dari konvensional ke komputerisasi (daftar bahan baku, bahan penolong, barang jadi, daftar persediaan). Inovasi lainnya iaut pengembangan desain produk dan kemasan serta integrase antar organisasi pentahelik A-B-G-C+M.

Permasalahan yang dihadapi oleh para pengrajin di Kampoeng Rajoet Binong jati yaitu para pengrajin masih kesulitan dalam pemanfaatan sosial media dalam memperkenalkan dan memasarkan produk rajutnya, pembuatan laporan keuangan atas usahanya masih bersifat tradisional dan bercampur dengan keuangan keluarga.

\section{METODE}

Metode pelatihan dalam kegiatan Pengabdian kepada Masyarakat ini berupa pelatihan yang menggunakan metode ceramah, praktek dan tanya jawab. Metode ceramah dilakukan dengan pemberian penjelasan materi facebook ad oleh tim materi dan kemudian para peserta mulai mempraktekan pembuatan facebook ad. Para peserta juga diberi kesempatan untuk melakukan sesi tanya jawab, berdiskusi dengan tim materi membahas persoalan atau kesulitan yang dihadapi dalam teknis pembuatan facebook ad seperti isi content yang perlu ditampilkan dalam facebook ad, informasi untuk proses transaksi, dll.

Kegiatan pelatihan berisi antara lain ceramah, contoh dan tanya jawab. Kegiatan ini dilakukan melalui virtual conference menggunakan googlemeet berkaitan dengan masih berlangsungnya pandemic corona

\section{HASIL DAN PEMBAHASAN}

Kegiatan PKM ini memberikan hasil berupa pencapaian tujuan pelatihan, pencapaian target materi yang direncanakan, penguasaan materi pelatihan dan dan implementasi facebook ad oleh peserta PKM agar dapat mengembangkan peluang usaha terbatas menjadi peluang usaha yang dapat menghasilkan profit secara maksimal selama pandemic corona. Jumlah peserta yang mendaftar dan hadir mengikuti kegiatan pelatihan sebanyak 20 orang. Jumlah peserta yang hadir tidak lepas dari peran komunitas sentra rajut untuk terus mendorong anggotanya mengembangkan usaha melalui pemasaran berbasis internet. Hal tersebut menunjukkan bahwa kegiatan PKM berdasarkan jumlah peserta yang ikut serta dinilai berhasil/ sukses. Pencapaian tujuan pelatihan dan implementasi facebook ad agar dapat mengembangkan peluang usaha terbatas menjadi peluang usaha yang dapat menghasilkan profit secara maksimal, maka dapat diambil kesimpulan bahwa bahwa tujuan kegiatan PKM ini tercapai. Hal ini ditunjukkan dengan antusiasme para peserta bertanya dan sharing ilmu selama kegiatan tanya jawab. Penguasaan target materi pada kegiatan PKM ini cukup baik karena materi pelatihan dan implementasi facebook ad agar dapat mengembangkan peluang usaha terbatas menjadi peluang usaha yang dapat menghasilkan profit secara maksimal. Secara keseluruhan kegiatan pelatihan dan implementasi facebook ad agar dapat mengembangkan peluang usaha terbatas menjadi peluang usaha yang dapat menghasilkan profit secara maksimal berjalan sesuai rencana dan para peserta mendapatkan ilmu baru. 


\section{PENUTUP}

\section{KESIMPULAN DAN SARAN}

Berdasarkan hasil survey dan wawancara, diidentifikasi bahwa permasalahan yang pada umumnya memiliki kendala yang sama yaitu pasar yang stagnan bahkan cenderung turun sebagai akibat pandemic corona, sehingga butuh promosi yang mampu memperluas jangkauan pemasaan dengan biaya yang tidak begitu mahal. Berdasarkan hasil identifikasi terhadap ketersediaan sarana dan pengetahuan yang dimiliki UMKM pada umumnya, maka disepakati bahwa sosial media yang digunakan adalah web commercial, Facebook dan Instagram atau WhatApp. Pembuatan content sosial media bagi UMKM untuk memasarkan produknya sudah belum tercapai 100\%. Sudah dilakukan Pelatihan pemasaran produk secara umum menggunakan sosial media menggunakan smartphone.

Berdasarkan pelaksanaan kegiatan yang telah dilaksanakan, dirasakan perlu dilakukan pendampingan dan pemberian motivasi secara berkesinambungan agar sosial media yang sudah dibuat dapat terus memberi manfaat bagi perluasan jangkauan pemasaran. Saran dari peserta yaitu mereka menginginkan pelatihan lanjutan berkaitan dengan Instagram.

\section{DAFTAR PUSTAKA}

Creeber, G. and Martin, R. 2009. Digital Cultures: Understanding New Media, Berkshire- England: Open University Press.

Diamond, Stephanie. 2015. The Visual Marketing Revolution. Jakarta : Serambi Ilmu Semesta.

Elvinaro Ardianto, Bambang Qomaruzzaman. 2016. Filsafat Ilmu Komunikasi, Bandung : Simbiosa Rekatama Media.

Haque, M. G., Nurjaya, N., Affandi, A., Erlangga, H., \& Sunarsi, D. (2021). Micro Financial Sharia Non-bank Strategic Analysis: a Study at BMT Beringharjo, Yogyakarta. Budapest International Research and Critics Institute (BIRCI-Journal): Humanities and Social Sciences, 4(2), 1677-1686.

Kingsnorth, Simon. 2016. Digital Marketing Strategy. London: Koran Page.
Lukiastuti, Fitri, et.al (2020). The Influence of Entrepreneur's Personal Characteristics on SMES Performance Mediated by Entrepreneurial Orientation. International Journal of Psychosocial Rehabilitation. Volume 24 - Issue 8.

M Nisrina. 2015. Bisnis Online : Manfaat Media Sosial dalam Meraup Uang. Yogyakarta : Kobis.

Maddinsyah, A., et al (2020). Analysis of location selection effect on the user decision that influcence the success of the service business of micro, small and medium enterprise (MSME) in bandung timur region. International Journal of Advanced Science and Technology. Vol. 29 No. 06.

McQuail, Denis. 2011. Teori Komunikasi Massa McQuail, Edisi 6 Buku 1. Jakarta: Salemba Humanika.

Williams, B.K. and Sawyer, S.C. 2011. "Using Information Technology: A Practical Introduction to Computers \& Communications. (9th edition)". New York: McGraw-Hill. 